\title{
An empirical comparison of wealth measurement and the role of built asset investment
}

\begin{abstract}
Purpose

The purpose of this paper is to assess the role of investment in built assets in the achievement of economic growth as part of a wealth measurement approach and to undertake an analysis of the relative importance of such investment as part of a country's overall capital asset portfolio.
\end{abstract} Research approach

Panel data on capital asset investment are used to compare groups of countries at different stages of development.

\section{Statistical sources}

Data sets on investment and capital levels from the Penn World Tables (PWT) 9.0.

Population and GDP data are taken from the same source and the UN Statistics Division. World Bank reports provide data on countries' income group classification.

\section{Findings}

There is confirmation of the view that, as economies grow, a pattern of investment based on developing a different structure of capital asset portfolio occurs. Investment patterns similar to those found in advanced countries arise as low income countries move to higher income classification groups even though built assets remain the most valuable capital asset group.

\section{Value}

The study provides time series evidence on the nature of changing capital investment patterns in countries' economies and demonstrates the value of a wealth measurement approach.

KEYWORDS: Built assets; Economic growth; Investment; Sustainability; Wealth measurement.

\section{Research Paper}




\section{Introduction}

\section{Wealth measurement}

When assessing the performance of an economy, measures based on national income (such as gross domestic product (GDP)) are current or short-run indicators with little consideration of the capital base of an economy. Accounting for the capital wealth of a nation provides a different perspective from that of GDP for assessing the performance of an economy by switching the focus of attention from flows (income) to stock metrics (wealth). This approach stresses the importance of preserving a portfolio of capital assets to ensure that an economy's productive base can be maintained. The production of new buildings and other structures in any given period adds to a nation's economic wealth, in the form of the built environment contributing to and complementing its productive and social capital.

Economic theory indicates that there is a strong link between changes in wealth and the sustainability of economic development and the question needs to be considered of how the resources expended on developing a country's built environment impact its economic (and social) success. Dependent upon a country's specific circumstances in terms of its environment, one issue concerns how the different components and of wealth vary across countries and how the shares of investment in different types of capital asset vary according to its level of development.

\section{Frameworks for wealth evaluation}

There have been two initiatives in recent years to develop a framework for the evaluation of the total wealth of an economy and they involve quite different approaches to such calculation. The first involves measurement by estimating the total wealth (top-down) and then breaking it down into various types of capital. This is the World Bank approach adopted in the reports Where Is the Wealth of Nations? Measuring Capital for the $21^{\text {st }}$ Century?, The Changing Wealth of Nations: Measuring Sustainable Development in the New Millennium and The Changing Wealth of Nations: Building a Sustainable Future (World Bank 2006, 2011, 2018), where total wealth is measured by:

Wealth $=$ Produced capital + Natural capital + Intangible capital (with the latter consisting of human capital and social capital). Since it is challenging to measure wealth by summing observed or estimated values of various types of capital, the World Bank estimated total wealth based on economic theory (Hamilton 
and Hartwick, 2005) and according to this theory, wealth is equal to the present value of future consumption, where consumption equals what is spent on market goods and services plus net investment in various types of capital. A time horizon of 25 years was assumed throughout the calculation of wealth and, for consumption purposes, a pure rate of time preference of $1.5 \%$ (a rate that a rational consumer would use) was assumed. Since the focus was on sustainable development, a social discount rate on investment of $4 \%$ was assumed. The perpetual inventory method was employed to estimate the value of produced capital including built assets.

The other approach involves summing the values of all the individual types of capital to estimate the total wealth (bottom-up approach). This is the approach adopted in the Inclusive Wealth Report 2012 (IWR) a joint initiative of the United Nations University - International Human Dimensions Programme (UNU-IHDP) and United Nations Environment Programme (UNEP) (UNU-IHDP and UNEP, 2012). The IWR provides a 'balance sheet' utilising a monetary measure that sums up the stock of natural, human and physical assets and formulates an Inclusive Wealth Index (IWI) to enable estimation of the degree of change in wealth levels and its component parts over time. Whilst the contribution of the construction sector to physical assets through buildings, infrastructure etc. is obvious, its role in influencing human capital (education and skills) through, for example, the design of schools and its role in affecting the value of natural capital (land-use, minerals, forests etc.) are also significant. The IWR emphasises the importance of sustainable development and one of the key areas in this context is the use and development of the built environment. As one of the main components of the country's wealth, the structures and their collective placement play a major role in determining the quantity and quality of all economic activities.

The IWR is sub-titled Measuring Progress towards Sustainability and the evaluation methodology is based on the development by Arrow et al (2012) of a consistent and comprehensive framework for assessing whether economic growth is compatible with sustaining well-being over time in an approach that concentrates on wealth rather than income. While the calculations for inclusive wealth may be considered crude (just as they were for GDP seventy years ago), the fact is that national economic policy-making is now an asset management problem and an accurate evaluation of an economy's assets is a prerequisite for such management.

Underlying any wealth account is an implicit production function, relating to the combinations of different assets with which a given level of output can be achieved, to show the relationship between the availability of different amounts of inputs, such as built assets and human capital 
services, and the maximum output that could be produced by using different output combinations. If a full and valid data set of asset values were available, the substitutability between inputs would allow the estimation of a production function that includes the services from these different resources as inputs. In such an idealised situation, variations across countries and changes over time can be explained in terms of the national availability of human resources, natural resources and physical capital including built structures. One overall finding from the report is that there are clear signs of trade-off effects among different forms of capital. The usefulness of data on capital assets is that they can allow an evaluation of existing measures and policies affecting the development of economies. Figure 1 shows the composition of capital in countries at different levels of development based on the World Bank's method of country classification by income level. (See later sections for more detail on World Bank country classification). The diagram shows considerable differences in the relative levels of different categories of capital asset between the country groups. As economies move from a subsistence level to manufacturing and service-based economies, they do so through the addition of human capital and produced capital, especially infrastructure and other built assets.

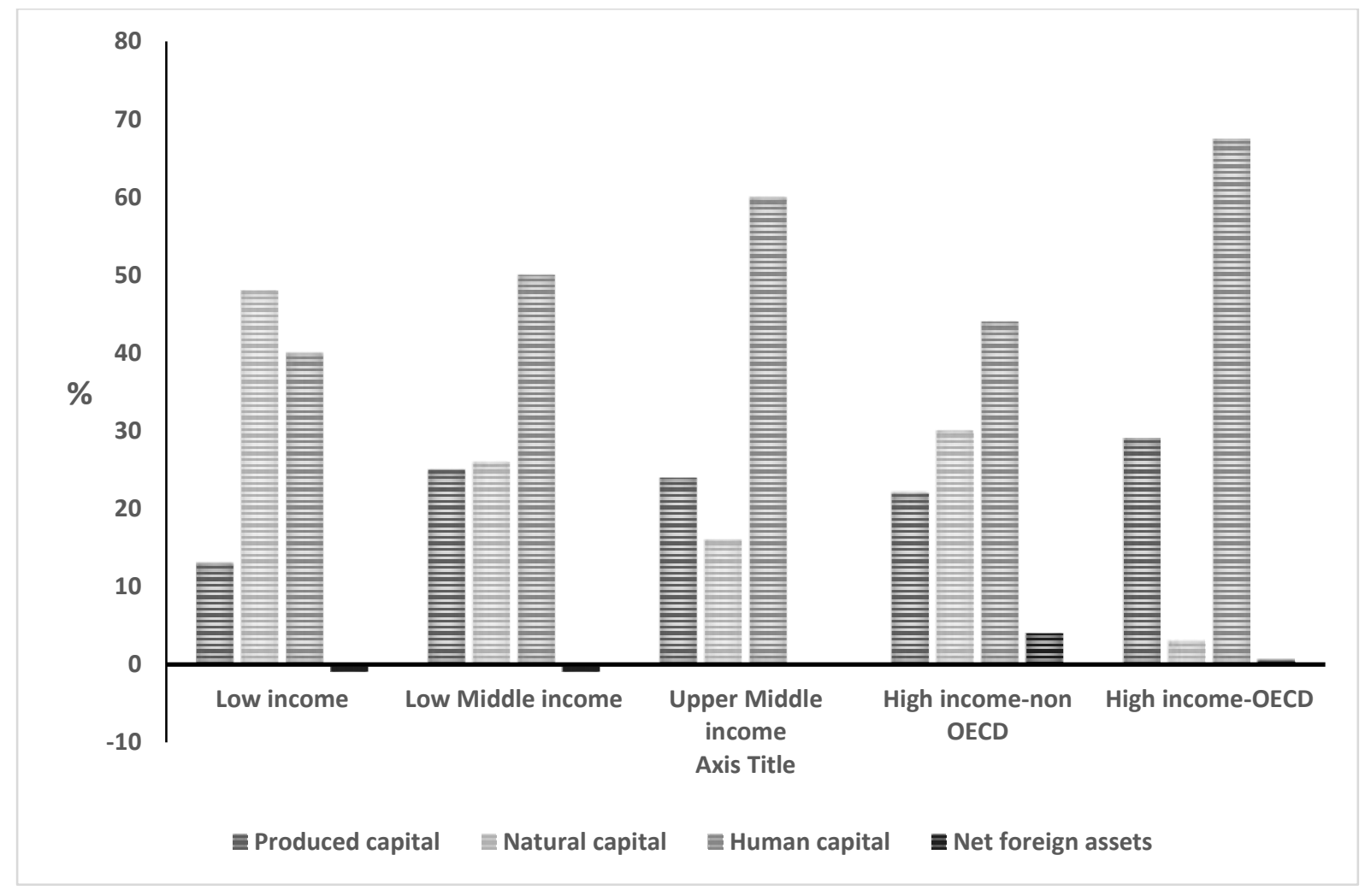

Figure 1 The composition of capital assets (\%) by country income classification in 2014 Source: World Bank (2018) 


\section{The role of investment in built assets}

As countries go through stages of development, so the need for different levels and types of built asset changes. From meeting basic needs in subsistence level economies, societal and economic requirements determine the dynamic role of built assets in a progressive manner, which is stylized in the hierarchical fashion depicted in Table 1.

A strategically planned and well-maintained built environment is critical to the economic and social success of a nation and the establishment of a foundation based on buildings and infrastructure is a fundamental priority for development.

\section{Table 1 Stages of built asset needs through development stages}

\begin{tabular}{|l|l|}
\hline $\begin{array}{l}\text { Advanced } \\
\text { economies }\end{array}$ & $\begin{array}{l}\text { Culture, status and luxury: } \\
\text { leisure, prestige projects, iconic buildings }\end{array}$ \\
\cline { 2 - 2 } & $\begin{array}{l}\text { Tertiary economy: } \\
\text { commercial sector, advanced transport, higher education }\end{array}$ \\
\cline { 2 - 2 } $\begin{array}{l}\text { Secondary economy: } \\
\text { economies }\end{array}$ & $\begin{array}{l}\text { factories, mass transport, basic education and healthcare } \\
\text { housing transport, utilities etc }\end{array}$ \\
\hline
\end{tabular}

The importance of built assets in an economy's capital stock

The construction and civil engineering industries are contributors to a country's capital stock in terms of infrastructure output. Mainstream macroeconomic theory on infrastructure has been based on a premise that increased investment in infrastructure increases the levels of efficiency and profitability in the economy.

In the Harrod-Domar model of economic growth, a positive increase in fixed capital investment is needed for an economy to grow. In broad terms, fixed investment (measured by gross fixed capital formation (GFCF)) can be split into structures investment and equipment. Structures investment is the fixed capital investment produced by the construction and civil engineering industry - the new factories, offices, roads and other transport facilities and improvements to existing ones. Equipment refers to the vehicles and pieces of machinery, tools and electronics used in conjunction with structures and, obviously, built structures have pieces of equipment 
(heating systems etc.) embodied in them. Once embodied in a structure, they become a part of it and can be included in the structures category of investment.

\section{Patterns of infrastructure investment}

Many studies have looked at the value to a country's economy of raising the level of its capital stock and indicated the positive role of infrastructure spending. Ball's (1997) study of structures investment in advanced economies covering a time series from 1850 showed that gross structures investment in aggregate was far greater than equipment investment in all the advanced countries considered. Aschauer (1993) sought to establish an econometric link between macro-level infrastructure investment and aggregate productivity and this empirical work was underpinned by Krugman's (1991) theoretical model, in which the provision of infrastructure such as road and rail lowered transport costs enable increasing returns. And, in a later work, Aschauer (1999) took the view that the large social returns that accrue to public works mean that investment in structures gives the greater boost to economic development. Ozkan et al (2011) analysed the relationship between infrastructure spending and GDP for the period 1987-2008 for Turkey and found that public infrastructure investment exerted long-term effects on GDP. Similarly, Fan and Zhang (2004) and Donaldson (2018) advanced the proposition that infrastructure supported increased income and productivity.

Based on historical data for the period from Mitchell (1988) for a time series from 1760 to 1980, it was estimated that built assets accounted for around 66-90\% of all man-made wealth. Coupled with a World Bank (1997) time series for over 100 countries showing that human capital accounted for $75 \%$ of the value of all assets of advanced European economies, with man-made assets accounting for most of the remainder, this indicated that built assets (if valid extrapolation is possible) would comprise about $16-22 \%$ of all wealth. The data show that built wealth has fallen as a fraction of all man-made wealth, which is consistent with the rise of an industrialised and post-industrialised society. As Barras (2009) indicated, the share of the equipment element of total capital stock tends to increase over time at the expense of the building component, which was a stylized fact proposed by Kaldor in 1961. An empirical study by Carassus et al (2004) showed that the workload of the construction sector in developed countries had changed considerably by the beginning of the twenty first century due to the rise of the tertiary sector of the economy and the simultaneous decline in demand for new construction work which, in the study, constituted only around a half of construction work in the developed western countries. 
Other studies have concluded, however, that it is difficult to generalise the built asset investment effects on the economy. Grebler and Burns (1982) in their analysis of construction cycles in the United States highlighted the complexities in the relationship between the cycles of total construction and most other economic sectors due to the differing factors determining the level of fixed investment in each sector. They recognised that 'Few generalizations survive the test of empirical investigation because each construction cycle possesses significant elements of uniqueness, as does each GNP cycle.' (p144). The results of their analysis (based on US data from 1950-78) are consistent with the hypothesis that changes in financial conditions are prime determinants of the residential cycle and that private non-residential construction reflects largely the factors determining private fixed investment. Public undertakings respond to forces quite different from those which influence private activity. Gruneberg (2010), based on a study of twenty six European Union countries, came to the conclusion that there is no discernible pattern to the level of expenditure on infrastructure and he argued that the pattern of infrastructure spending in countries did not follow the inverted $U$ shaped pattern indicated by Bon (1992). Infrastructure is one sub-market of construction activity in which it is difficult to discern the pattern, mainly due to the 'lumpiness' of infrastructure investment projects.

\section{Negative aspects of infrastructure investment}

While much evidence has stressed the positive aspects of investment in built assets, other studies have shown that construction investments can have a negative impact on economic growth. Kocherlakota and Yi (1996) suggested that infrastructure investments do not necessarily improve the economic growth rate and Ganesan (2000) found that excessive supply of construction outputs even caused recessions in South East Asia in 1997, in Singapore in 1985 and in Trinidad and Tobago around the same time. According to Giang and Pheng (2010), excessive growth of construction activity might negatively affect the macroeconomic stability by misallocation and waste of resources

Calderon et al (2015) used an infrastructure-augmented production function approach including as inputs, infrastructure assets to consider the contribution of infrastructure capital to aggregate productivity and output. Their panel dataset consisted of eighty-eight industrial and developing countries over the period 1960-2000. This large variety of data and empirical methodologies provided widely contrasting empirical results but they found the marginal product of infrastructure was higher when the (relative) infrastructure stock was lower but then diminished at higher levels. 
Ansar et al (2016) considered the question of whether China's economic growth over the period 1984-2008 was a consequence of its infrastructure investment in order to test the view that a high level of infrastructure investment is a precursor of growth and could be a model for other countries to follow. Their conclusion was to reject the orthodox theory that heavy investment in infrastructure causes economic growth and to proffer the view that overinvesting in underperforming projects has instead led to 'economic fragility'. The study, based on an assessment of the impact of project-level infrastructure in China considered ninety-five large Chinese road and rail projects and eight hundred and six transport projects in developed countries. It suggested that a massive infrastructure programme is not a viable development programme for other developing countries, who may look to China as a model for economic development. They concluded that it is a myth that, over that period, China grew largely due to heavy infrastructure investment. At a microeconomic (i.e. project-based level), for more than a half of the infrastructure investments in China, the costs were greater than the benefits generated, which means that the projects destroy economic value. They quote Zeng Peiyan, the former minister in charge of China's State Development Planning Commission (The New York Times , 24 September 1998): 'Only if infrastructure investment grows by 15 to 18 percent (per year), can we reach 8 percent economic growth'. The massive growth in investment in infrastructure was a strategy based on the premise that a larger stock of infrastructure is thought to fuel economic growth by reducing the cost of production and transport of goods and services, increasing the productivity of input factors, creating indirect positive externalities, and smoothing the business cycle. Ansar et al argue that what might be considered to be a strength of the Chinese system has instead led to colossal waste. All this construction produced cost overruns equal to one third of China's $\$ 8.2$ trillion debt pile in 2014. This challenges the conventional belief that the more you build, the more you lower costs for businesses and households and add to economic growth.

\section{Research methodology}

Given the mixed evidence of previous studies, this study aims to evaluate the role of investment in built assets as part of a country's overall capital investment portfolio and to examine that changing role for countries at different levels of development. The data requirement for the study requires valid data on built asset investment, total investment, and gross domestic product for a number of countries at different stages of development. The use of panel data allows both inter-temporal and inter-national comparisons to be made. 


\section{Data on built assets}

For over four decades, the Penn World Table (PWT) has been a standard source of data on national economies. It is a set of national accounts data developed to measure real GDP across countries and over time. Making use of prices collected across countries in benchmark years by the International Comparisons Program (ICP) and using these prices to construct purchasing-power-parity (PPP) exchange rates, PWT converts national economic data to a common currency (\$US) allowing inter-country comparisons.

The latest version of the PWT (version 9.0) (Feenstra et al, 2015) is a database with information on relative levels of income, output, input and productivity, covering one hundred and eighty two countries between 1950 and 2014, meaning that it provides a set of economic time-series based on national accounts covering most of the countries in the world. For this research, estimates of physical capital are obtained from the database, which uses the perpetual inventory method to estimate produced capital stocks The physical capital estimates include the value of structures, machinery, and equipment, because the value of the stocks is derived from gross capital formation data that account for these elements. They provide information for four separate asset groups: structures (including residential and non-residential), machinery (including computers, communication equipment and other machinery), transport equipment and other assets (including software, other intellectual property products and cultivated assets). For each of the four assets, the capital detail file includes information on investment at constant national prices, the investment deflator, the current-cost net capital stock, the capital stock deflator and capital consumption at current prices.

\section{Data on economic development}

This study is concerned with the changing reliance on investment in built assets as countries' resource needs change with their stage of economic development. There are various ways of assessing a country's stage of economic development. For this research, World Bank classification data are used and the focus for the analysis is on those countries that experienced levels of economic development, which resulted in elevation of their classification status over a period of time.

In the World Development Indicators (World Bank, 2017), all one hundred and eighty nine World Bank member countries are classified by income group. Economies are divided into four income groupings: Low (L), Lower-Middle (LM), Upper-Middle (UM) and High (H). Income is measured using gross national income (GNI) per capita (in \$US) converted from local 
currency using the World Bank Atlas method. Estimates of GNI are obtained from economists in World Bank country units and countries are reassigned on July 1 each year, based on the estimate of their GNI per capita for the previous calendar year.

From the time series datasets, it is possible to see how any country's classification status has changed over time. The 2017 Report provides data for the period 1987-2014. Over this period, forty-two countries experienced an upward movement in their World Bank classification based on GNI per capita; these countries will be referred to as 'improving countries'. The main classifications provided are by geographic region and by income group and, when grouped by geographical region, the list of those with improved status is shown in Table 2.

Table 2 Country classification by geographical region

\begin{tabular}{|c|c|c|c|c|c|c|c|}
\hline \multicolumn{2}{|c|}{$\begin{array}{l}\text { Latin America and } \\
\text { Caribbean }\end{array}$} & \multicolumn{2}{|c|}{ Europe and Central Asia } & \multicolumn{2}{|c|}{ Africa and MENA } & \multicolumn{2}{|c|}{$\begin{array}{l}\text { Southern and } \\
\text { Eastern Asia }\end{array}$} \\
\hline Country & $\begin{array}{l}\text { Change in } \\
\text { status }\end{array}$ & Country & $\begin{array}{l}\text { Change } \\
\text { in status }\end{array}$ & Country & $\begin{array}{l}\text { Change } \\
\text { in status }\end{array}$ & Country & $\begin{array}{l}\text { Change } \\
\text { in status }\end{array}$ \\
\hline Chile & $\mathrm{LM} \rightarrow \mathrm{H}$ & Croatia & $\mathrm{LM} \rightarrow \mathrm{UM}$ & Ghana & $\mathrm{L} \rightarrow \mathrm{LM}$ & China & $\mathrm{L} \rightarrow \mathrm{H}$ \\
\hline Colombia & $\mathrm{LM} \rightarrow \mathrm{UM}$ & Czech Rep & $\mathrm{LM} \rightarrow \mathrm{H}$ & Mauritius & $\mathrm{LM} \rightarrow \mathrm{UM}$ & India & $\mathrm{L} \rightarrow \mathrm{LM}$ \\
\hline Ecuador & $\mathrm{LM} \rightarrow \mathrm{UM}$ & Estonia & $\mathrm{UM} \rightarrow \mathrm{H}$ & Namibia & $\mathrm{LM} \rightarrow \mathrm{UM}$ & S. Korea & $\mathrm{UM} \rightarrow \mathrm{H}$ \\
\hline Grenada & $\mathrm{LM} \rightarrow \mathrm{UM}$ & Greece & $\mathrm{UM} \rightarrow \mathrm{H}$ & Nigeria & $\mathrm{L} \rightarrow \mathrm{LM}$ & Maldives & $\mathrm{L} \rightarrow \mathrm{UM}$ \\
\hline Guyana & $\mathrm{L} \rightarrow \mathrm{LM}$ & Hungary & $\mathrm{UM} \rightarrow \mathrm{H}$ & Oman & $\mathrm{UM} \rightarrow \mathrm{H}$ & Pakistan & $\mathrm{L} \rightarrow \mathrm{LM}$ \\
\hline Jamaica & $\mathrm{LM} \rightarrow \mathrm{UM}$ & Latvia & $\mathrm{LM} \rightarrow \mathrm{H}$ & Tunisia & $\mathrm{LM} \rightarrow \mathrm{UM}$ & $\begin{array}{l}\text { Sri } \\
\text { Lanka }\end{array}$ & $\mathrm{L} \rightarrow \mathrm{LM}$ \\
\hline Panama & $\mathrm{LM} \rightarrow \mathrm{UM}$ & Lithuania & $\mathrm{LM} \rightarrow \mathrm{H}$ & Zambia & $\mathrm{L} \rightarrow \mathrm{LM}$ & Thailand & $\mathrm{LM} \rightarrow \mathrm{UM}$ \\
\hline Paraguay & $\mathrm{LM} \rightarrow \mathrm{UM}$ & Macedonia & $\mathrm{LM} \rightarrow \mathrm{UM}$ & & & Tonga & $\mathrm{LM} \rightarrow \mathrm{UM}$ \\
\hline Peru & $\mathrm{LM} \rightarrow \mathrm{UM}$ & Poland & $\mathrm{LM} \rightarrow \mathrm{H}$ & & & Vietnam & $\mathrm{L} \rightarrow \mathrm{LM}$ \\
\hline $\begin{array}{l}\text { St. Kitts \& } \\
\text { Nevis }\end{array}$ & $\mathrm{UM} \rightarrow \mathrm{H}$ & Portugal & $\mathrm{UM} \rightarrow \mathrm{H}$ & & & & \\
\hline $\begin{array}{l}\text { Trinidad } \\
\text { \& Tobago }\end{array}$ & $\mathrm{UM} \rightarrow \mathrm{H}$ & Slovak Rep & $\mathrm{LM} \rightarrow \mathrm{H}$ & & & & \\
\hline \multirow[t]{3}{*}{ Uruguay } & $\mathrm{UM} \rightarrow \mathrm{H}$ & Slovenia & $\mathrm{LM} \rightarrow \mathrm{H}$ & & & & \\
\hline & & Turkey & $\mathrm{LM} \rightarrow \mathrm{UM}$ & & & & \\
\hline & & Turkmenistan & $\mathrm{LM} \rightarrow \mathrm{UM}$ & & & & \\
\hline
\end{tabular}

The classification table, being based on discrete annual data, depicts a picture of a 'stepped change' over the period but the trend is, of course, normally a progressive one from one year to the next. The change in status column in Table 2 indicates the upward movement in 
classification between 1987 and 2014. For example, Chile was classified as a Lower-Middle income economy in 1987 but had attained High income classification by 2014 .

When the countries are grouped according to their change in status (Table 3), the majority (thirty-two) achieved an increase in status of one classification but eight (mainly the accession countries to the European Union in the 1990s) raised their status by two classifications. China was exceptional, in moving up three classifications from Low to High income over the period.

Table 3 Country classification by income group

\begin{tabular}{|l|l|}
\hline \multicolumn{2}{|c|}{ Change in status between 1987 and 2014 } \\
\hline $\mathrm{L} \rightarrow \mathrm{LM}$ & Guyana, Ghana, Nigeria, Zambia, India, Pakistan, Sri Lanka, Vietnam \\
\hline $\mathrm{LM} \rightarrow \mathrm{UM}$ & $\begin{array}{l}\text { Colombia, Ecuador, Grenada, Jamaica, Panama. Paraguay, Peru, Croatia, } \\
\text { Macedonia, Turkey, Turkmenistan, Mauritius, Namibia, Tunisia, Thailand }\end{array}$ \\
\hline $\mathrm{UM} \rightarrow$ H & $\begin{array}{l}\text { St. Kitts \& Nevis, Trinidad \& Tobago, Uruguay, Estonia, Greece, Hungary, } \\
\text { Portugal, Oman, South Korea }\end{array}$ \\
\hline $\mathrm{LM} \rightarrow$ H & Chile, Czech Republic, Latvia, Lithuania, Poland, Slovak Republic, Slovenia \\
\hline $\mathrm{L} \rightarrow \mathrm{UM}$ & Maldives \\
\hline $\mathrm{L} \rightarrow \mathrm{H}$ & China \\
\hline
\end{tabular}

\section{Analysis and Findings}

Of these forty-two countries, the PWT have data on all of them except Tonga and so forty-one countries are included in the analysis. The length of the time series data on investment available for analysis varies between the groups. For all the listed Southern and Eastern Asian countries, a full dataset from 1960 onwards is available; for Africa and MENA it is 1961; for the Latin American and Caribbean countries it is $1970 ; 1990$ is the start date for the series on Central and Eastern Europe, Baltic states and ex-CIS countries and so restricts the Europe and Central Asia series for analysis to this start date.

Therefore, this means that, for most of the countries, changes in investment in assets are available for a considerable period prior to 1987 and a longer term trend can be determined.

\section{Benchmark}

In this analysis of the 'improving countries', a benchmark group of countries against which to make comparisons is taken - using data from the PWT 9.0, it is the G7 group (Canada, France, 
Germany, Italy, Japan, UK and USA) the seven largest advanced economies in the world. Figure 2 shows the average (mean) value of the capital stock for the G7 group over the period 1950-2014. In terms of the value of the capital stock, the value of structures has risen steadily since 1960 and is by far the largest component of capital assets in terms of value. This high level of built asset value does, of course represent an accumulation of value over a lengthy period of economic development for these advanced economies.

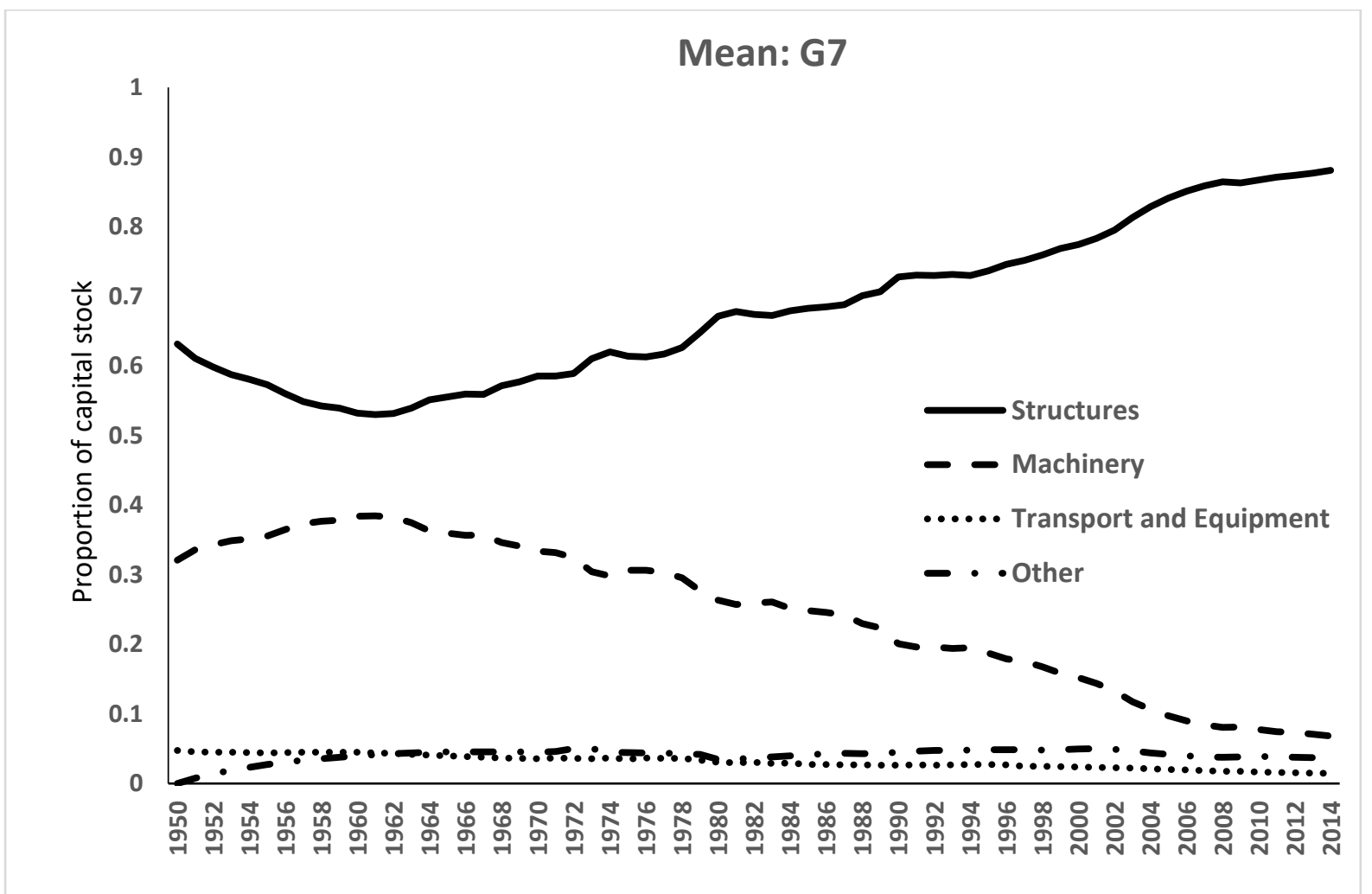

Figure 2 Relative value of capital stock by category as proportion of total capital stock. Mean for the G7 countries.

However, the importance of investment in new built assets shows a different picture. In Figure 3 , the trend for investment in structures indicates that this has been at a relatively consistent level of 50-60\% (averaging 54\% over the sixty-five year period) of total annual investment since 1950. This level can be considered to be the norm for advanced economies even through the unevenness of fluctuations of economic cycles. 


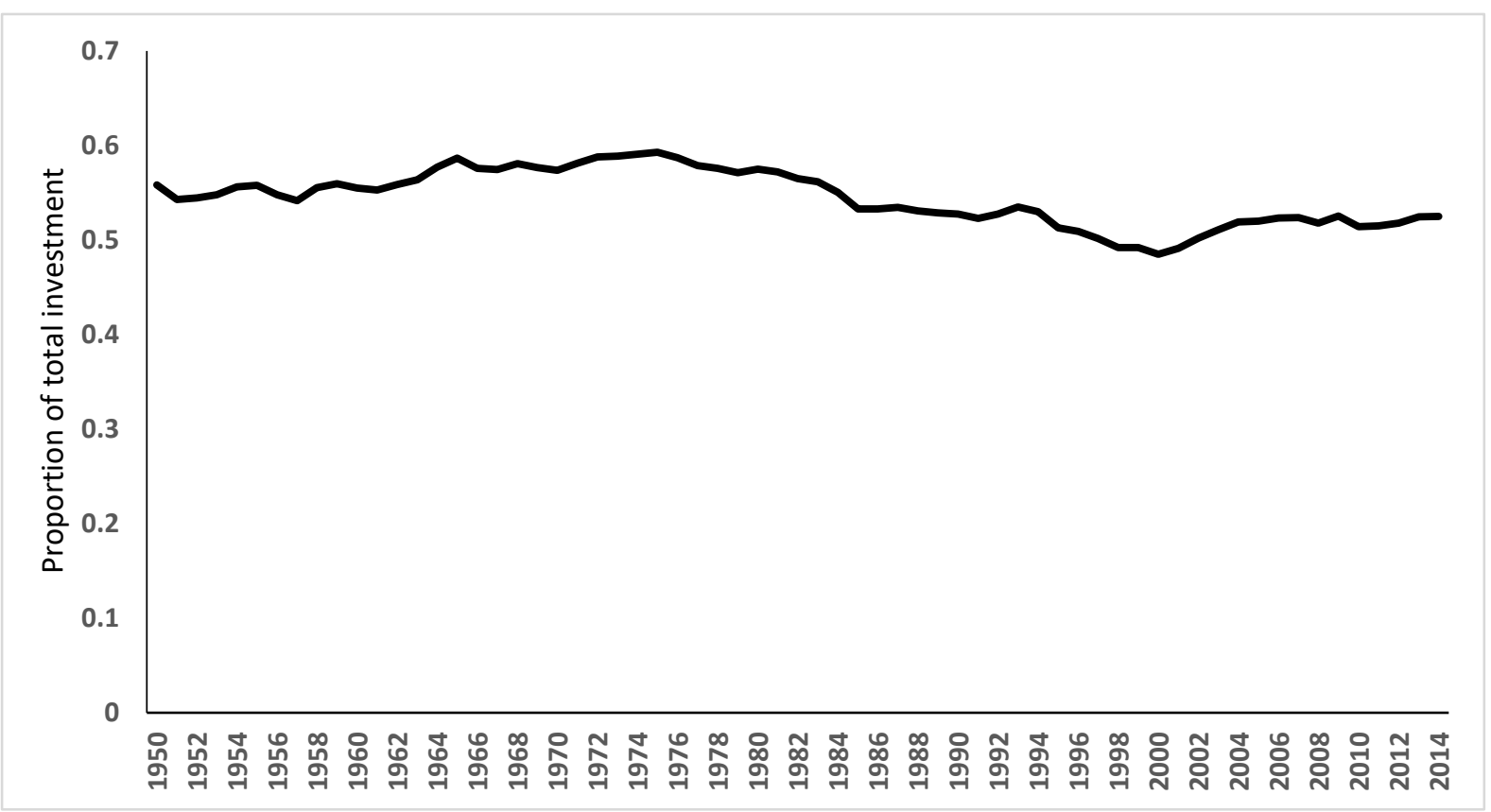

Figure 3 Investment in structures as a proportion of total investment.

\section{Mean value for the $\mathbf{G} 7$ countries}

The 'improving' economies

The mean value levels of investment in built assets calculated as a proportion of total asset investment for the countries classified by income group are shown in Figures 4a-f and Table 4 shows the summary descriptive statistics on the 'improving' economies by income classification group. 


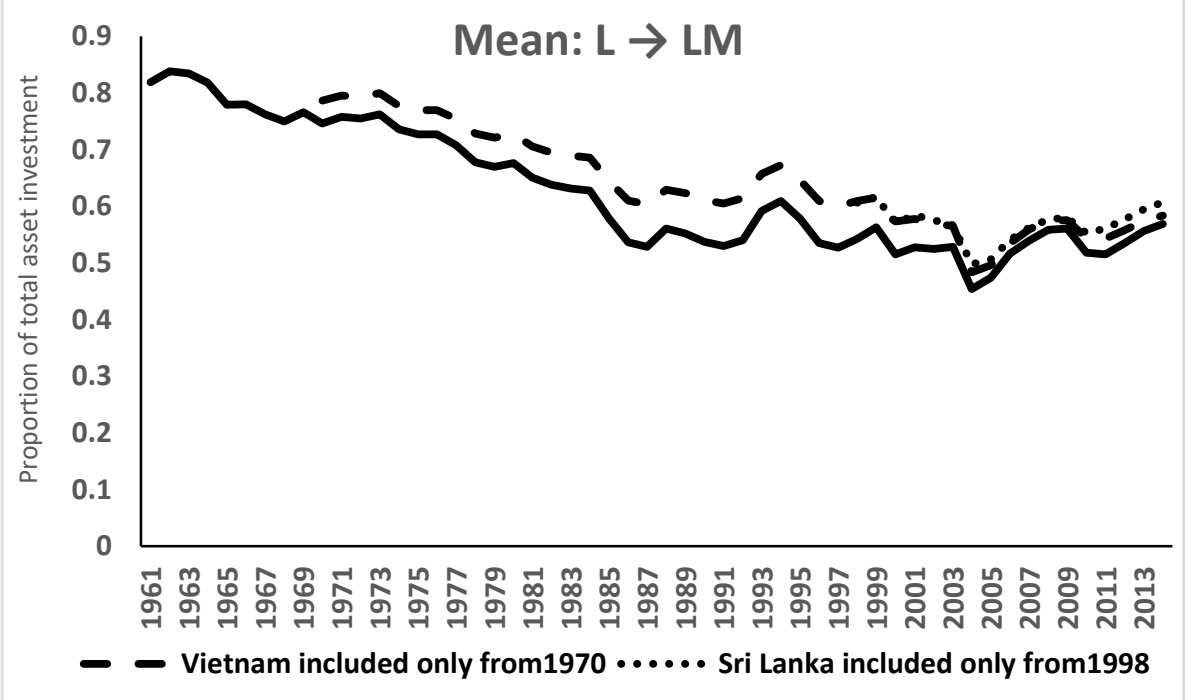

Figure 4a

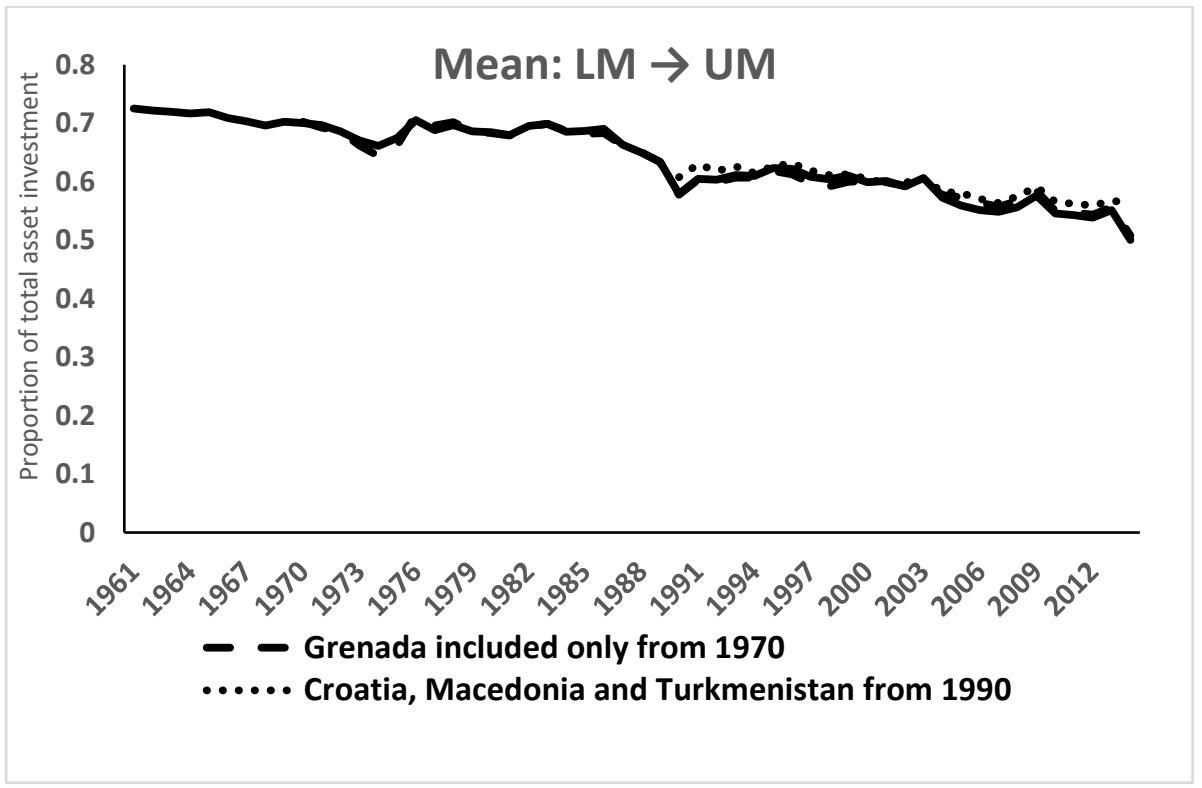

\section{Figure 4b}




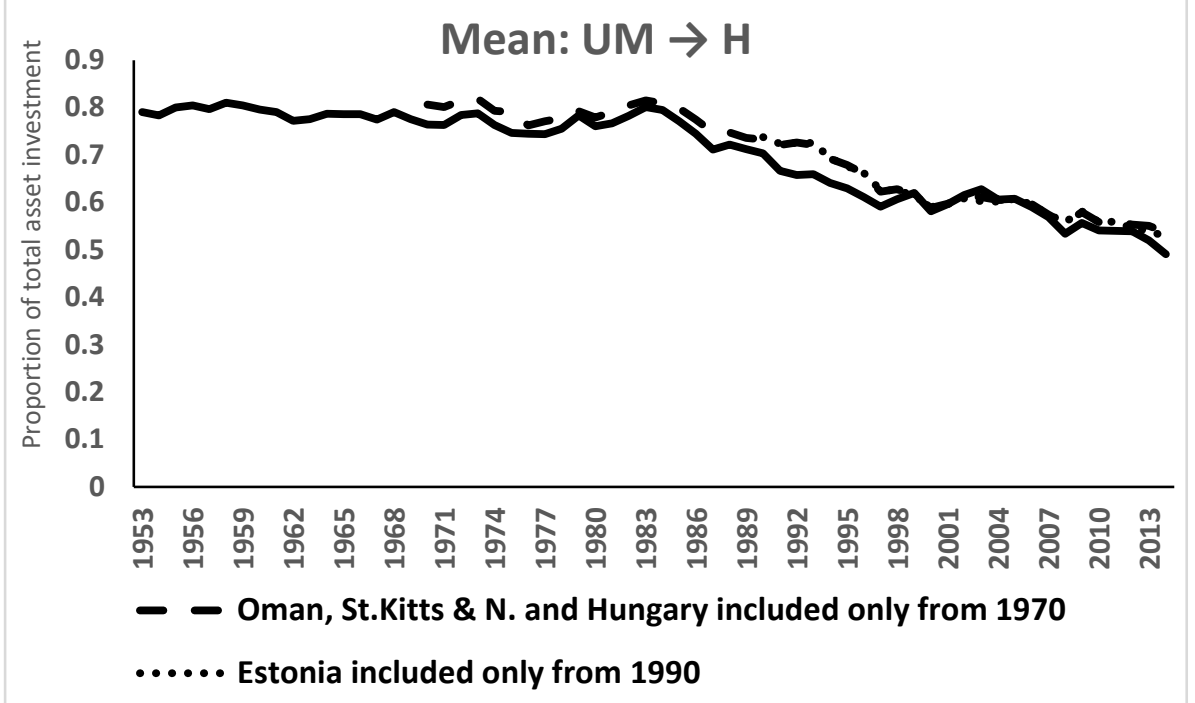

Figure 4c

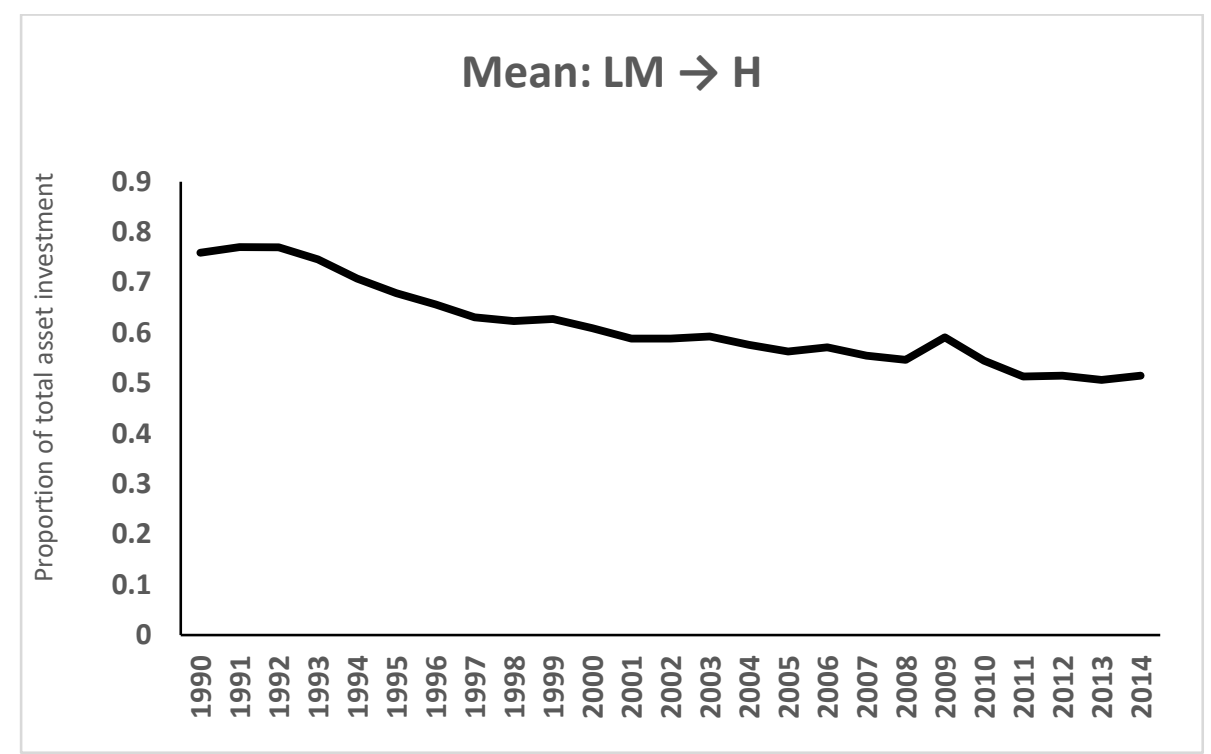

Figure 4d 


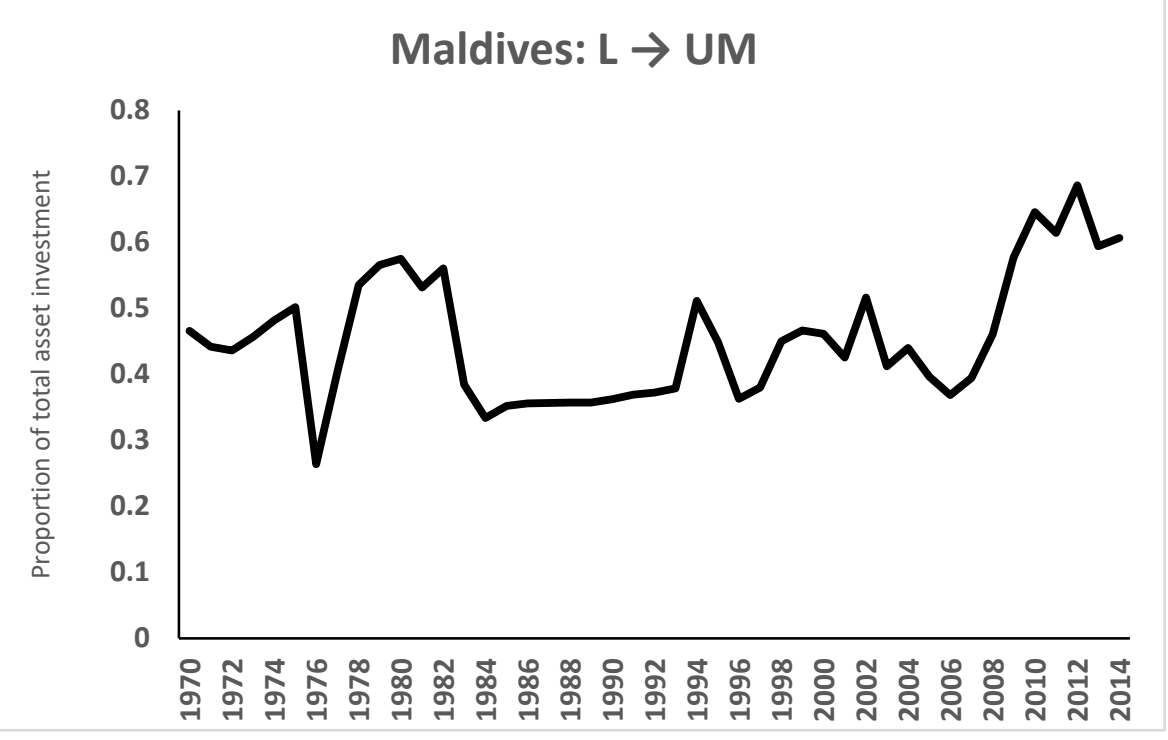

Figure 4e

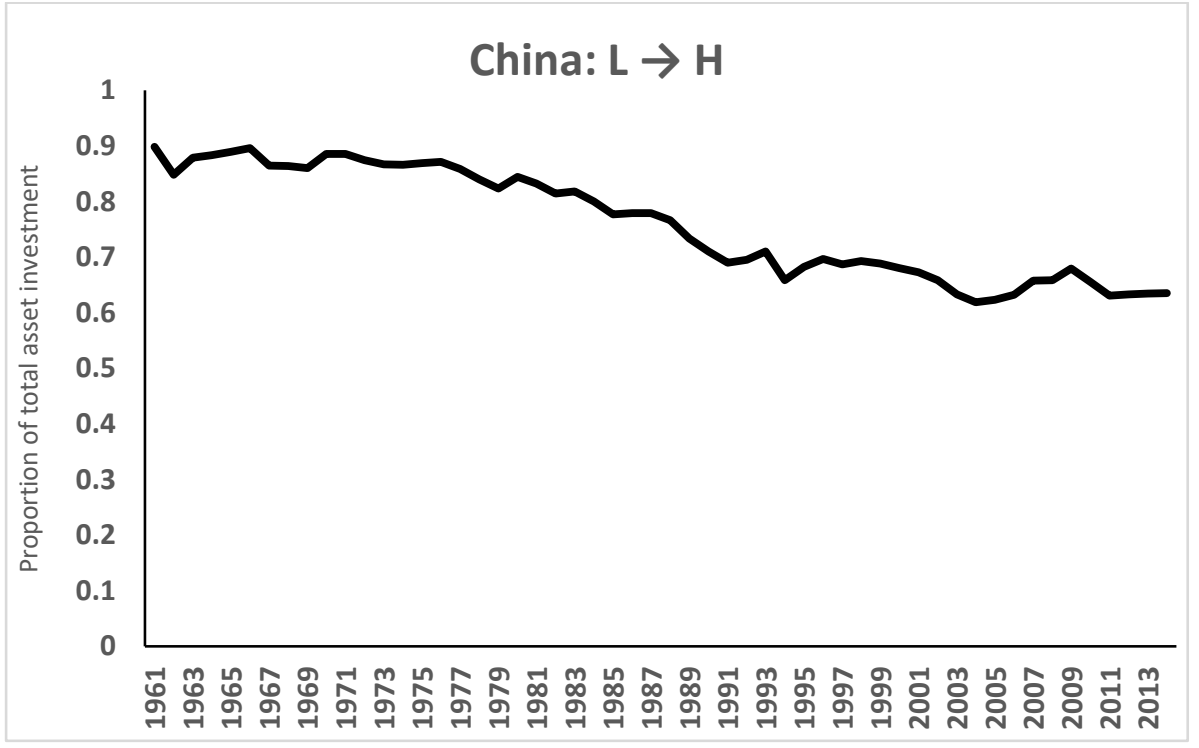

Figure 4f

Figures 4 (a-f) Mean proportion of overall investment in structures (by income classification)

Table 4 Summary statistics: Proportion of investment in structures

\begin{tabular}{|l|ll|l|l|}
\hline \multicolumn{6}{|l|}{ Change from Low to Lower Middle Income } \\
\hline & Mean (standard dev.) & Lowest & Highest \\
\hline 1961 & 0.819 & $(0.097)$ & 0.714 (Zambia) & 0.908 (India) \\
\hline 1987 & 0.603 & $(0.267)$ & 0.235 (Zambia) & 0.978 (Vietnam) \\
\hline 2014 & 0.607 & $(0.088)$ & 0.516 (Ghana) & 0.747 (Sri Lanka) \\
\hline
\end{tabular}


Comments: The data from 1961 incorporates six countries. From 1970 onward, it also includes Vietnam, whose level remained above 0.9 until 1999, raising the overall mean and standard deviation values. Sri Lanka is included from 1998.

\section{Change from Lower Middle to Upper Middle Income}

\begin{tabular}{|l|ll|l|l|}
\hline 1961 & 0.725 & $(0.026)$ & 0.476 (Paraguay) & 0.851 (Panama) \\
\hline 1987 & $0.666(0.113)$ & 0.503 (Tunisia) & 0.861 (Colombia) \\
\hline 2014 & $0.565(0.138)$ & 0.295 (Thailand) & 0.667 (Namibia) \\
\hline
\end{tabular}

Comments: The data from 1961 incorporates eleven countries. Plus Grenada from 1970 and Croatia, Macedonia and Turkmenistan from 1990.

\section{Change from Upper Middle to High Income}

\begin{tabular}{|l|ll|l|l|}
\hline 1953 & 0.791 & $(0.219)$ & 0.421 (Trinidad \&T) & 0.932 (Greece) \\
\hline 1987 & 0.747 & $(0.155)$ & 0.392 (Trinidad \&T) & 0.848 (Hungary) \\
\hline 2014 & 0.528 & $(0.097)$ & 0.454 (Estonia) & 0.736 (St. Kitts \&N) \\
\hline
\end{tabular}

Comments: The data from 1953 incorporates five countries. From 1970 onwards, Hungary, Oman and St. Kitts \& Nevis are added. Estonia from 1990.

\section{Change from Lower Middle to High Income}

\begin{tabular}{|l|ll|l|l|}
\hline 1990 & 0.759 & $(0.180)$ & 0.478 (Slovakia) & 0.983 (Lithuania) \\
\hline 2014 & $0.515(0.086)$ & 0.407 (Slovakia) & 0.628 (Chile) \\
\hline
\end{tabular}

Comments: Data is available from 1951 only for Chile. Data from the six counties that joined the European Union is only available from 1990 and so the illustrated series is only shown from the latter year.

\section{Change from Low to Upper Middle Income (Maldives)}

\begin{tabular}{|l|l|l|l|}
\hline 1970 & 0.466 & & \\
\hline 1987 & 0.357 & & \\
\hline 2014 & 0.607 & & \\
\hline
\end{tabular}

Comments: Volatility due to special circumstances; most notably the government's policy to expand infrastructure for the tourism sector post-2008.

\section{Change from Low to High Income (China)}

\begin{tabular}{|l|l|l|l|}
\hline 1961 & 0.898 & & \\
\hline 1987 & 0.780 & & \\
\hline 2014 & 0.635 & & \\
\hline
\end{tabular}




\section{Conclusions}

\section{Relative levels of built asset investment}

The special circumstances of the Maldives apart, the clear trend depicted in Figures $4(a-f)$ is that of a steady reduction over time in the proportion of overall investment that is in structures and built assets. While lower-income economies have been devoting significantly more of their output to investment, including built assets, in recent decades in an effort to catch up economically, the fall in the relative importance of investment in built assets is apparent. The mean proportion for all the forty-one countries for 2014 is 0.559 . In other words, a fall to the level that is comparable to that found in the advanced countries of the G7.

\section{Built assets and asset management policy}

Since Kuznets work in the 1930s, GDP has been used as the main measurement tool in the assessment of the state of a country's economy and evaluation of its economic progress. Yet macroeconomic policy making should be based on asset management and a wealth measurement approach used to evaluate economic progress. Measurement of a country's built environment assets is a prerequisite of successful resource management and the substitutability and complementarity of different forms of assets are essential aspects of a production function style approach.

Advanced economies with a well-developed but ageing built environment and diversified economic base are faced with changing needs in the use of the built environment (for example from manufacturing to service based industries) and need to continue to invest in new and existing built assets to improve productivity and standard of living. Built assets tend, by nature, to have a long life and the focus is, therefore, on extending the life of existing assets and redefining built asset use through regeneration.

In their approaches to investment in built environment assets, countries at earlier stages of development may choose different paths. Some countries, such as India, Nigeria and Pakistan have faced huge challenges as a result of rapid population growth, urbanisation and economic transformation. Built assets need to be developed to address big challenges around the basic need for social infrastructure as well as productive capital. Part of the focus in these countries is in the planning and creation of basic assets, which meet rapidly increasing social need, and development is about managing a broad portfolio of assets in terms of produced, natural and human capital. In other emerging economies (such as Chile), investment in built assets is an enabler for their economy to develop, often on the 
back of resource derived wealth. The focus in these markets is on the planning and creation of assets that have a real impact and will be sustainable for the long term. For different countries, their paths of development will obviously differ according to resource availability and the dynamics of the environment in which they find themselves. Various reports (see for instance ECHarris, 2013) on emerging and developing countries have indicated that they have been devoting significantly more of their GDP to investment including built assets in recent decades in an effort to catch up economically. This is in keeping with the earlier findings of Ruddock and Lopes (2006), who put forward the view that, generally, as an economy reaches an advanced stage, the volume of construction activity reduces relatively but not absolutely. The type of activity changes as countries develop, as those with an established building stock find that building activity becomes more orientated towards repair and maintenance and this activity is not included as investment or capital formation in the national accounting system.

The findings from the panel data approach used in this analysis add credibility to this proposition. A purpose of this paper is to assess the role of investment in built assets in the achievement of economic growth and this has been based on a wealth measurement approach, concerned with undertaking an analysis of the relative importance of such investment as part of a country's overall capital asset portfolio. Particularly for developing countries, a capital asset investment approach to sustainable development requires the establishment of a foundation for economic success based on buildings and infrastructure.

\section{References}

Ansar, A., Flyvbjerg, B., Budzier, A. and Lunn, D. (2016), “Does infrastructure investment lead to economic growth or economic fragility? Evidence from China”, Oxford Review of Economic Policy, Vol. 32, Number 3, 360-390.

Arrow, K., Dasgupta, P., Goulder, L.H., Mumford, K. and Oleson, K. (2012), “Sustainability and the measurement of wealth", Environment and Development Economics, Vol.17 (03), 317353

Aschauer, D. A. (1993), “Genuine Economic Returns to Infrastructure Investment”, Policy

Studies Journal 21 (2), 380-90

Aschauer, D. A. (1999), “Is Public Expenditure Productive?”, Journal of Monetary Economics, 23, 176-200. 
Ball, M. (1997), "Structures Investment and International Economic Growth: The Historical Record", in Construction Economics and Econometrics, Proceedings of the 55 ${ }^{\text {th }}$ International Conferences of the Applied Econometrics Association, Neuchâtel, February 1997.

Barras, R. (2009), Building cycles - Growth and instability, Wiley-Blackwell, Chichester.

Bon, R. (1992), "The future of international construction: Secular patterns of growth and decline", Habitat International, 16, 119-28.

Calderón, C., Moral-Benito, E. and Servén, L. (2015), "Is infrastructure capital productive? A dynamic heterogeneous approach", Journal of Applied Econometrics, Vol.30, 177-198.

Carassus, J. (ed.) (2004), The Construction Sector System Approach: An International Framework, Report by CIB W055-W065 Construction Industry Comparative Analysis Project Group, CIB, Rotterdam.

Donaldson, D. (2018), "Railroads of the Raj: Estimating the Impact of Transportation Infrastructure", American Economic Review 2018, 108 (4-5), 899-934.

EC Harris (2013), Global Built Asset Wealth Index 2013, accessed at: www.arcadis.com Fan, S. and Zhang, X. (2004) "Infrastructure and regional economic development in rural China”, China Economic Review 15 (2), 203-214.

Feenstra, Robert C., Robert Inklaar and Marcel P. Timmer (2015), "The Next Generation of the Penn World Table" American Economic Review, 105(10), 3150-3182.

Ganesan, S. (2000) Employment, Technology and Construction Development: With Case Studies in Asia and China, Routledge, Oxford.

Giang, D.T.H and Pheng, L.S. (2010), "Role of construction in economic development:

Review of key concepts in the past 40 years", Habitat International, 35, 118-25.

Grebler, L. and Burns, L.S. (1982) "Construction Cycles in the United States since World War Two", Real Estate Economics, Vol.10 (2), 123-151.

Gruneberg, S. (2010), Does the Bon curve apply to infrastructure markets? In: Egbu, C. (Ed) Proceedings $26^{\text {th }}$ Annual ARCOM Conference, September 2010, Leeds, Association of Researchers in Construction Management, 33-42.

Hamilton, K. and Hartwick, J. (2005), "Investing Exhaustible Resource Rents and the Path of Consumption", Canadian Journal of Economics, 38, 2, 615-621.

Kaldor, N. (1961) “Capital accumulation and economic growth”, in F.A. Lutz and D.C. Hague eds., The Theory of Capital, Macmillan, London, 177-222.

Kocherlakota, N.R. and Yi, K. (1996), "Simple time series test of endogenous vs. exogenous growth models: An application to the United States", Review of Economics and Statistics, 78(1), 126-134. 
Krugman, P. (1991), "Increasing Returns and Economic Geography", Journal of Political Economy ,99 (3), 483- 99.

Mitchell, B. (1988), British Historical Statistics, Cambridge University Press, Cambridge. OECD (2018), OECD Database, accessed at http://www.oecd.org/statistics/

Ozkan, F., Ozkan, O. and Gunduz, M. (2011), "Causal relationship between construction investment policy and economic growth in Turkey", Technological Forecasting and Social Change, Vol. 79, 362-370.

Ruddock, L. and Lopes, J. (2006) The construction sector and economic development: The 'Bon curve', Construction Management and Economics, 24(7), 717-23

UNU-IHDP and UNEP (2012), Inclusive Wealth Report 2012. Measuring progress toward sustainability, Cambridge University Press, Cambridge.

World Bank (1997), Expanding the Measure of Wealth: Indicators of Environmentally Sustainable Development, World Bank, Washington DC.

World Bank (2006), Where Is the Wealth of Nations? Measuring Capital for the 21st Century?, World Bank, Washington DC.

World Bank (2011), The Changing Wealth of Nations: Measuring Sustainable Development in the New Millennium, World Bank, Washington DC.

World Bank (2017), World Development Indicators, World Bank, Washington DC.

World Bank (2018), The Changing Wealth of Nations: Building a Sustainable Future, World Bank, Washington DC. 